\title{
Hydrological water balance modelling for assessing productivity and irrigation planning
}

\author{
M. B. Nagdeve, G. K. Ramteke \& P. A. Kamble \\ Dr. Panjabrao Deshmukh Agricultural University, Akola, India
}

\begin{abstract}
The physically based distributed modelling system, MIKE SHE, is used to simulate the hydrological water balance of Belura watershed with the objective of developing the irrigation plan and assessing productivity. The existing cropping system was replaced with the cropping system planned using qualitative land evaluation i.e. land capability and suitability classification for soils of the watershed. The hydrological water balance was simulated using calibrated model for Belura watershed. The actual yield of the sorghum, cotton and pigeonpea from watershed area was estimated by Food and Agriculture Organisation (FAO) model, using simulated hydrological water balance. Yield of sorghum, cotton and pigeonpea is estimated to be 32,48 and $55 \%$ of the potential yield at downstream side and 28,41 and $46 \%$ at upstream side, respectively. Considering the water requirement to obtain potential yields, these crops suffered soil moisture deficit of 61,68 and $151 \mathrm{~mm}$ at upstream; and 57,65 and $157 \mathrm{~mm}$ at downstream sides of the watershed, respectively. If irrigation is provided as and when water content in the root zone goes below allowable limit at different crop growth stages using hydrological water balance, it is possible to obtain sustainable crop yields. The overall results illustrate the applicability of MIKE SHE comprehensive hydrological modelling system for the management of water resources for sustainable agricultural productivity in a watershed.
\end{abstract}

Keywords: hydrological modelling, hydrological water balance, land capability, land suitability, storie index rating, crop planning, and irrigation planning.

\section{Introduction}

Land, water and vegetation are the most important natural resources for survival of mankind, to satisfy the need for food, fibre and fuel and other material. In 
recent year, the land productivity is continuously declining because of overexploitation and degradation of natural resources. It resulted in static and some times even a significantly lower agricultural production. Watershed management has become the cornerstone of planning and development of land and water resource. Hydrological simulation models are often used to provide information as a basis for decisions regarding the development and management of water and land resources.

MIKE SHE (Refsgaard and Storm [11]) is a comprehensive deterministic, distributed and physically based modelling system for the simulation of all the major hydrological process occurring in the land phase of the hydrological cycle. MIKE SHE is a further development based on the SHE modelling concept. It has been widely adopted for catchment studies (Barthurst [3, 4]; Refsgard et al. [12]; Jain et al. [8]). It simulates water flow, water quality and sediment transport.

Land evaluation is a process of assessment of land performance, which is essential step in crop planning. It is the process of grouping the soils in to various groups in relation to their crop productivity. The productivity of soil is defined with the realized yields of economic crops. The evaluation of soils may be qualitative and quantitative. The modified FAO relationship can estimate the actual yield of different crops on the basis transpiration. With this background a present investigation was formulated to develop crop plan and irrigation plan by assessing productivity of Belura watershed.

\section{Methodology}

\subsection{Study area and data}

This study concentrates on Belura watershed, which is located in the Patur Tahsil of Akola district. The watershed lies between $76^{\circ} 53^{\prime} 00^{\prime \prime}$ to $76^{\circ} 54^{\prime} 55^{\prime \prime} \mathrm{E}$ longitudes and $20^{\circ} 32^{\prime} 20^{\prime \prime}$ to $20^{\circ} 33^{\prime} 54^{\prime \prime} \mathrm{N}$ latitudes with an altitude ranging from 300 to $343 \mathrm{~m}$ above MSL covering an area of about 577ha. The location map of the Belura watershed is presented in fig.1. The climate of the area is semi-arid, characterized by three distinct seasons viz., hot and dry summer, warm and rainy monsoon, and dry mild winter. Average maximum and minimum temperature is $42^{\circ} \mathrm{C}$ and $10^{\circ} \mathrm{C}$ in the month of May and December, respectively. The total rainfall received during the year 2000 was $573.4 \mathrm{~mm}$ as against normal rainfall is about $824.7 \mathrm{~mm}$ during the last 25 years (1971 to 1995). Most of the rainfall in the area occurs during June to September.

\subsection{Land use}

Land use/ land cover classification and mapping of the study area was carried out with the help of Geocoded (1:12,500) IRS 1C AND 1D LISS III and PAN images. The PAN sharpened image of the study area was visually interpreted. Based on the photographic elements like tone, texture, shape, size and pattern etc., the various land unit boundaries were delineated. These land units were then confirmed by ground verification and finally the study area was grouped in to seven land use/land cover classes and presented in fig. 2 . 


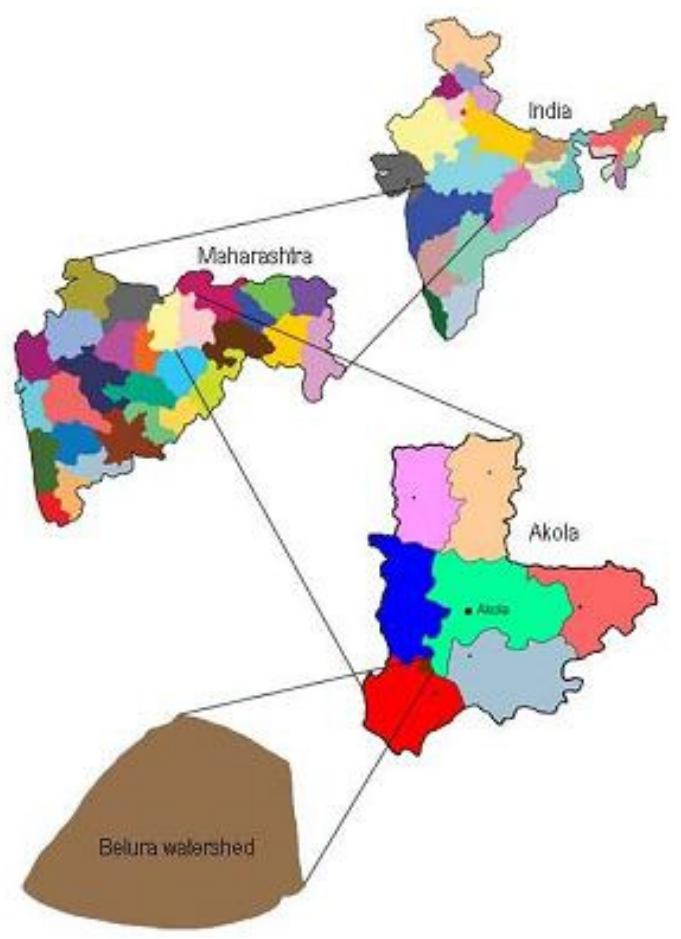

Figure 1: $\quad$ Location map of Belura watershed.

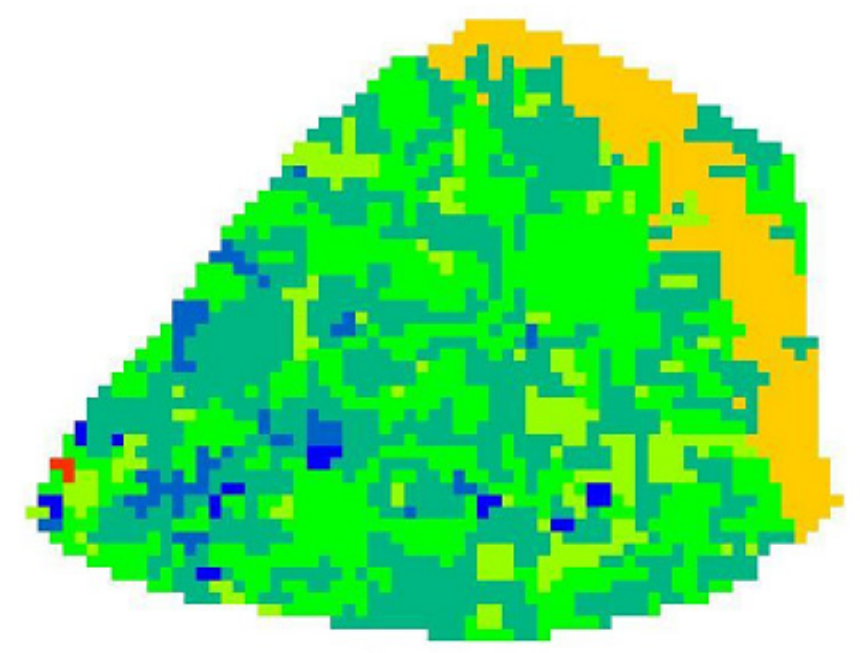

Figure 2: $\quad$ Landuse/land cover map of the watershed. 


\subsection{Land evaluation}

The productivity of soil is defined with the realized yields of economic crops. As the crop yields are dependent on climate as well as soil-site factors, integration of these factors are necessary to obtain yields. The evaluation of soil may be qualitative or quantitative. In the present study both types of evaluation of seven soils have been done as suggested by USDA (Klingebiel and Montgomery [9] and FAO [5]. The levels of limitations were used as defined by FAO [6, 7]. The crop planning has been done using qualitative land evaluation i.e. land capability and suitability classification for the soils of the watershed. Storie index rating (Storie [14]) was used for quantitative land evaluation.

\subsection{Description of MIKE SHE}

MIKE SHE is a comprehensive deterministic, distributed and physically based modelling system for the simulation of all major hydrological processes occurring in the land phase of the hydrological cycle. Two analogous horizontalgrid square networks discretize the model area for surface and subsurface groundwater flow components. A vertical column of nodes at each grid representing the unsaturated zone of MIKE SHE model. A finite difference solution of the partial differential equation, describing the process of overland and channel flow, unsaturated and saturated flow, interception and evapotranspiration, is used for water balance modelling. The overall model structure is illustrated in fig. 3. Description of its components is given in Abbott et al. [1, 2]; Refsgaard and Storm [11].

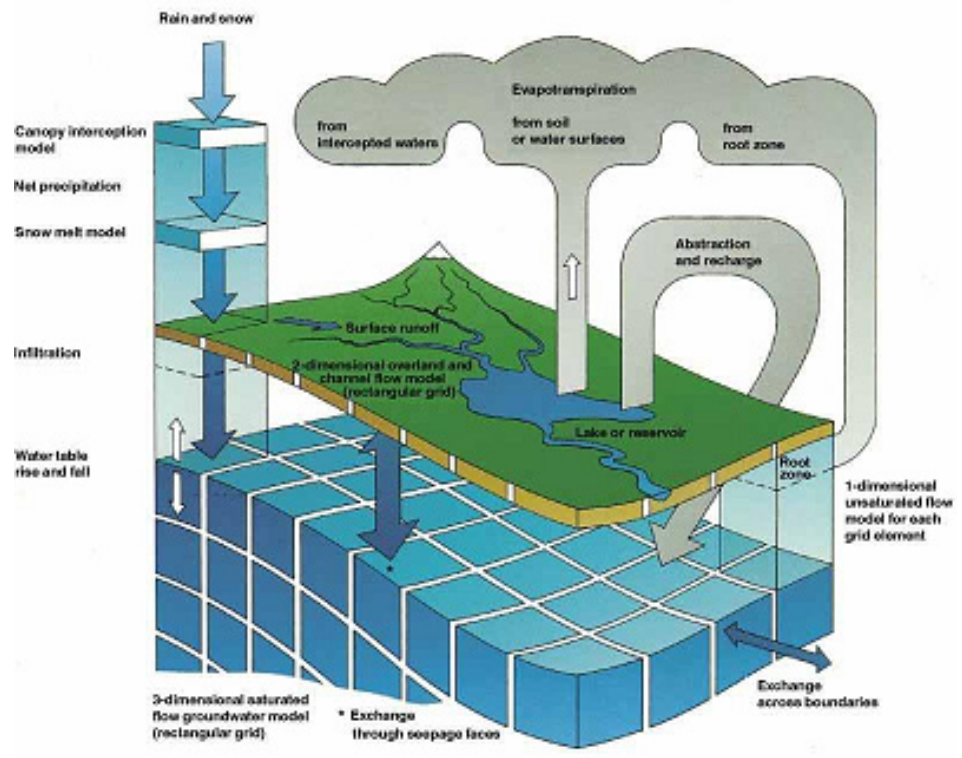

Figure 3: $\quad$ Schematic representation of MIKE SHE. 


\subsection{Model simulation}

MIKE SHE model calibrated for the Belura watershed was used to simulate the hydrological water balance using suggested crop planning for the season 2001 . The daily hydrological water balance is essential for assessing the yield of the different crops, which is suggested by the qualitative evaluation.

\subsection{Evaluation of actual yield}

The actual yields of different crops from the area was evaluated by using the output of MIKE SHE model of the Belura watershed and the modified FAO relationship (Singh et al. [13]), with replacing evopotranspiration term with transpiration, which is given as

$$
\left(1-\frac{Y_{a}}{Y_{m}}\right)=\sum_{i=1}^{n} K_{y}^{i}\left(1-\frac{E_{a t}}{E_{m t}}\right)
$$

where, $Y_{a}=$ the actual yield, $Y_{m}=$ maximum attainable yield, $K_{y}=$ yield response factor, $E_{a t}=$ actual transpiration, $E_{m t}=$ maximum transpiration, $i$ $=$ crop growth stages. The value of $K_{y}$ for different crops is based on the evaluation of numerous research results, which cover a wide range of growing condition.

\section{Results and discussion}

\subsection{Land evaluation}

The evaluation of soils may be qualitative and quantitative. In present investigation both types of evaluation of soils were used.

\subsubsection{Qualitative evaluation}

The qualitative evaluation of the soils for crop production has been done by two ways viz. land capability classification and land suitability classification and presented below:

3.1.1.1 Land capability classification Soils of the watershed are described and according to their properties the land capability classes are assigned and presented in table 1 .

3.1.1.2 Land suitability classification Important climatic and soil-site characteristics were evaluated to determine the suitability of the soils for sorghum, cotton and pigeon pea, as these are major crops of the region. The results are presented in table $2 \mathrm{a}$ and $2 \mathrm{~b}$ for these crops. The crop requirement table compiled by NBSS and LUP [10] with some modification of crop requirement as given by Sys [15] were also used. The result indicated that the soils $\mathrm{Bk} 5 \mathrm{CB}(\mathrm{A}) 1$ and $\mathrm{Bh} 5 \mathrm{CB}(\mathrm{A}) 1$ are very suitable for cotton, sorghum and pigeon pea. $\mathrm{Bh} 4 \mathrm{CB}(\mathrm{A}) 1$ is moderately suitable for cotton, sorghum and pigeon pea. Similarly, Bh3CB(A)1 is also moderately suitable for sorghum. Tn2CB2, $\mathrm{Tn} 2 \mathrm{C} 1 \mathrm{~B} 2$ and $\mathrm{Tn} 2 \mathrm{C} 1 \mathrm{C} 3$ are unsuitable for cultivation. 
Table 1: $\quad$ Capability classification of the soils.

\begin{tabular}{|l|l|l|}
\hline Soil series & Description & LCC \\
\hline Bk5CB(A)1 & $\begin{array}{l}\text { Clay soils, deep, moderately well drained with 1-3 slope } \\
\text { and non-to slightly eroded. }\end{array}$ & IIe \\
\hline Bb3CB(A)1 & $\begin{array}{l}\text { Clay soils, shallow, well drained with 1-3 percent slope and } \\
\text { moderately eroded. }\end{array}$ & IVes \\
\hline Bh4CB(A)1 & $\begin{array}{l}\text { Clay soils, moderately deep, well drained with 1-3 percent } \\
\text { slope and moderately eroded. }\end{array}$ & IIIes \\
\hline Bh5CB(A)1 & $\begin{array}{l}\text { Clay soils, deep, moderately well drained with 1-3 percent } \\
\text { slope and non-to slightly eroded. }\end{array}$ & IIe \\
\hline Tn2CB2 & $\begin{array}{l}\text { Sandy clay loam soils, shallow, well drained, 1-3 percent } \\
\text { slope and moderately eroded. }\end{array}$ & VIes \\
\hline Tn2ClB2 & $\begin{array}{l}\text { Sandy clay loam soils, very shallow, well drained, 1-3 } \\
\text { percent slope and moderately eroded. }\end{array}$ & VIes \\
\hline Tn2ClC3 & $\begin{array}{l}\text { Sandy clay loam soils, very shallow, well drained with 3-5 } \\
\text { percent slope and severely eroded. }\end{array}$ & VIes \\
\hline
\end{tabular}

Table 2: (a) Climatic characteristics of soils and climatic suitability for Sorghum, Cotton and Pigeon pea. (b) Soil site characteristics selected for evaluation.

(a)

\begin{tabular}{|l|c|c|c|c|c|c|}
\hline Climatic Characteristics & Sorghum & LL $^{*}$ & Cotton & LL $^{*}$ & Pigeon pea & LL $^{*}$ \\
\hline Annual rainfall mm (1971-95) & 824.7 & 0 & 824.7 & 1 & 824.7 & 1 \\
\hline Rainfall in growing season, mm & 537.4 & 1 & 537.4 & 2 & 537.4 & 2 \\
\hline Length of growing period, days & 138 & 0 & 138 & 1 & 138 & 2 \\
\hline Mean temp in growing season, ${ }^{\circ} \mathrm{C}$ & 26.55 & 1 & 26.55 & 0 & 26.55 & 0 \\
\hline $\begin{array}{l}\text { Mean maximum temp. in growing } \\
\text { season, }{ }^{\circ} \mathrm{C}\end{array}$ & 34.0 & 2 & 34.0 & - & 34.0 & - \\
\hline $\begin{array}{l}\text { Mean minimum temp. in growing } \\
\text { season },{ }^{\circ} \mathrm{C}\end{array}$ & 19.1 & 1 & 19.1 & - & 19.1 & - \\
\hline $\begin{array}{l}\text { Mean relative humidity in growing } \\
\text { season, }{ }^{\circ} \mathrm{C}\end{array}$ & 62.0 & 0 & 62.0 & 0 & 62.0 & - \\
\hline Suitability class & $\mathrm{S} 2$ & $\mathrm{~S} 2$ & \multicolumn{2}{|c|}{$\mathrm{S} 2$} \\
\hline
\end{tabular}

*Level of limitations.

(b)

\begin{tabular}{|l|c|c|c|c|c|c|c|}
\hline \multirow{2}{*}{$\begin{array}{l}\text { Soil- site } \\
\text { characteristics }\end{array}$} & \multicolumn{7}{|c|}{ Soil types } \\
\cline { 2 - 8 } & Bk5CB(A)1 & Bb3CB(A)1 & Bh4CB(A)1 & Bh5CB(A)1 & Tn2CB2 & Tn2C1B2 & Tn2C1C3 \\
\hline Site characteristics & $1-3$ & $1-3$ & $1-3$ & $1-3$ & $1-3$ & $1-3$ & $3-5$ \\
\hline Slope, \% & e1 & e2 & e2 & e1 & e2 & e2 & e3 \\
\hline Erosion & Mod. well & Well & Well & Mod. well & Well & Well & Well \\
\hline Drainage & C & c & C & c & Scl & Scl & scl \\
\hline Soil characteristics & 118 & 30 & 76 & 112 & 20 & 15 & 15 \\
\hline Texture & C & & & & & \\
\hline Depth, cm & 11 &
\end{tabular}




\subsection{Quantitative evaluation}

The productivity index of upstream and downstream of soils of watershed has been calculated and presented in table $3 \mathrm{a}$ and $3 \mathrm{~b}$. The result showed that the Storie Index Rating (SIR) of the downstream and upstream sides of the watershed falls between 27.45 to 54.15 and 6.12 to 48.45 . The SIR of the downstream side is more than the upstream side of the watershed. The productivity class was found poor to fair class at downstream side and very poor to fair at upstream side of the watershed, as downstream side soils are always better than upper reaches. The higher SIR of soils produce more yields than the lower SIR of the soils

Table 3: (a) Storie index rating of different soils of downstream side watershed. (b) Storie index rating of different soils of upstream side watershed.

(a)

\begin{tabular}{|l|c|c|c|c|c|c|}
\hline Soil types & $\begin{array}{c}\text { Factor A } \\
\text { Depth }\end{array}$ & $\begin{array}{c}\text { Factor B } \\
\text { Textural }\end{array}$ & $\begin{array}{c}\text { Factor C } \\
\text { Slope }\end{array}$ & $\begin{array}{c}\text { Factor X } \\
\text { Drainage }\end{array}$ & SIR & $\begin{array}{c}\text { Productivity } \\
\text { Class }\end{array}$ \\
\hline $\mathrm{Bk5CB}(\mathrm{A}) 1$ & 100 & 60 & 95 & 95 & 54.15 & Fair \\
\hline $\mathrm{Bb} 3 \mathrm{CB}(\mathrm{A}) 1$ & 60 & 60 & 95 & 85 & 29.07 & Poor \\
\hline $\mathrm{Bh} 4 \mathrm{CB}(\mathrm{A}) 1$ & 85 & 60 & 95 & 85 & 41.18 & Fair \\
\hline $\mathrm{Bh} 5 \mathrm{CB}(\mathrm{A}) 1$ & 100 & 60 & 95 & 85 & 48.45 & Fair \\
\hline Tn2CB2 & 40 & 85 & 95 & 85 & 27.45 & Poor \\
\hline Tn2ClB2 & 40 & 85 & 95 & 85 & 27.45 & Poor \\
\hline
\end{tabular}

(b)

\begin{tabular}{|l|c|c|c|c|c|c|}
\hline Soil types & $\begin{array}{c}\text { Factor A } \\
\text { Depth }\end{array}$ & $\begin{array}{c}\text { Factor B } \\
\text { Textural }\end{array}$ & $\begin{array}{c}\text { Factor C } \\
\text { Slope }\end{array}$ & $\begin{array}{c}\text { Factor X } \\
\text { Drainage }\end{array}$ & SIR & $\begin{array}{c}\text { Productivity } \\
\text { Class }\end{array}$ \\
\hline Bk5CB(A)1 & 95 & 60 & 85 & 100 & 48.45 & Fair \\
\hline Bb3CB(A)1 & 40 & 60 & 85 & 95 & 19.38 & Poor \\
\hline Bh4CB(A)1 & 60 & 60 & 85 & 95 & 29.07 & Poor \\
\hline Bh5CB(A)1 & 95 & 60 & 85 & 95 & 46.02 & Fair \\
\hline Tn2CB2 & 20 & 85 & 85 & 95 & 13.72 & Poor \\
\hline Tn2ClB2 & 20 & 85 & 85 & 95 & 13.72 & Poor \\
\hline Tn2ClC3 & 20 & 85 & 60 & 60 & 6.12 & Very poor \\
\hline
\end{tabular}

Table 4: $\quad$ Suggested cropping plan.

\begin{tabular}{|l|c|c|c|c|}
\hline Present land use & Slope $\%$ & Soil series & Area, ha & Suggested crop \\
\hline $\begin{array}{l}\text { Double crops (Green } \\
\text { gram \& Black gram) }\end{array}$ & $1-3$ & $\mathrm{Bb} 3 \mathrm{CB}(\mathrm{A}) 1$ & 219.49 & Sorghum \\
\hline $\begin{array}{l}\text { Single crop (Short } \\
\text { duration, Sorghum) }\end{array}$ & $1-3$ & $\mathrm{Bh} 4 \mathrm{CB}(\mathrm{A}) 1$ & 120.46 & Cotton \\
\hline $\begin{array}{l}\text { Single crop (Long } \\
\text { duration, Cotton) }\end{array}$ & $1-3$ & $\mathrm{Bh} 5 \mathrm{CB}(\mathrm{A}) 1$ & 51.57 & Pigeon pea \\
\hline
\end{tabular}




\subsection{Crop planning}

The crop planning has been done using qualitative land evaluation i.e. land capability and suitability classification for the soils of watershed. The suggested crop planning of the study area has been briefly summarised in the table 4 .

\subsection{Water balance of the watershed}

MIKE SHE model calibrated for Belura watershed, to simulate hydrological water balance of the watershed with suggested crop scenario. The simulated values were used to evaluate the actual yield of the suggested crop.

\subsection{Evaluation of yield}

The actual yield of sorghum, cotton and pigeon pea crops from the area was evaluated by using the output of MIKE SHE model of the Belura watershed and the modified FAO relationship. The actual transpiration and maximum transpiration was estimated by deducting the soil evaporation from the actual and maximum evaptranspiration values, where the soil evaporation and actual evaptranspiration was estimated by using Kristensen and Jensen model. The actual yield of the crops viz. sorghum, cotton and pigeon pea at the upstream and downstream of watershed were calculated and presented in the table 5.

The result indicates that the actual yields of the sorghum, cotton and pigeon pea at downstream side of watershed were estimated to be $16.28,5.87$, and $7.72 q$ $\mathrm{ha}^{-1}$ and $14.09,4.91$ and $6.48 \mathrm{q} \mathrm{ha}^{-1}$ at the upstream side, respectively. The actual yields calculated by modified FAO relationship of sorghum, cotton and pigeon pea are estimated to be is 32,48 and $55 \%$ of the maximum yield of 50,12 and 14 $\mathrm{q} \mathrm{ha}^{-1}$, respectively

Table 5: Actual yields of Sorghum, Cotton and Pigeon pea estimated using modified FAO relationship and irrigation requirement.

\begin{tabular}{|l|c|c|c|c|c|c|}
\hline \multirow{2}{*}{ Crops } & \multicolumn{2}{|c|}{ Maximum yield, $\mathrm{q} \mathrm{ha}^{-1}$} & \multicolumn{2}{c|}{ Actual yield, $\mathrm{q} \mathrm{ha}^{-1}$} & \multicolumn{2}{c|}{ Irrigation required, $\mathrm{mm}$} \\
\cline { 2 - 7 } & Down & $\mathrm{Up}$ & Down & $\mathrm{Up}$ & Down & $\mathrm{Up}$ \\
\hline Sorghum & 50.00 & 48.00 & 16.28 & 14.09 & 61.18 & 64.70 \\
\hline Cotton & 12.00 & 10.00 & 5.87 & 4.91 & 67.92 & 57.21 \\
\hline Pigeon pea & 14.00 & 12.00 & 7.72 & 6.48 & 110.10 & 119.20 \\
\hline
\end{tabular}

\subsection{Irrigation plan}

The amount of water required to obtain maximum yield of the crops, the maximum evapotranspiration at different crop growth stages were taken from the model output and total irrigation requirement were calculated (table 5). The irrigation requirement at downstream side was found to be 61.18, 67.92 and 110.10 for sorghum, cotton and pigeon pea, respectively. Similarly, at upstream side these values are found to be $64.70,57.21$ and 119.20 , respectively. 


\section{Conclusions}

The actual yields, calculated using modified relationship developed by Food and Agriculture Organisation, of sorghum, cotton and pigeon pea are estimated to be 32,48 and $55 \%$ of the maximum yield of 50, 12 and $14 \mathrm{q} \mathrm{ha}^{-1}$, respectively. The estimated yield of the crops coincides with respective Storie Index Rating (SIR), which confirm the utility of SIR for crop planning of the watershed. The overall results illustrate applicability of the comprehensive hydrological modelling system, MIKE SHE, for management of water resources for sustainable agricultural productivity in a watershed.

\section{References}

[1] Abbott, M. B., Barthurst, J. C., Cunge, J. A., O’Connell, P. E. O. \& Rasmussen, J., An introduction to European Hydrological System Systeme Hydrologique Europeen, "SHE" 1: History and Philosophy of a physically based distributed modelling system. J. Hydrol., 87, pp. 45-59, 1986a.

[2] Abbott, M. B., Clarke, R. \& Preissmann, A., An introduction to European Hydrological System - Systeme Hydrologique Europeen, "SHE" 2: Structure of a physically based distributed modelling system. J. Hydrol., 87, pp. 60-79, 1986b.

[3] Bathurst, J. C., Physically based distributed modelling of upland catchment using the Systeme Hydrologique Europeen. J. Hydrol., 87, pp. 79-102, 1986a.

[4] Barthurst, J. C., Sensitivity analysis of the Systeme Hydrologique Europeen for an upland catchment. J. Hydrol., 87, pp. 103-121, 1986b.

[5] FAO, A frame works for land evaluation. FAO Soil Bull. No.32, Rome, pp. $72,1976$.

[6] FAO, Land evaluation for rainfed agriculture, FAO Soil Bull. No.52, Rome, pp. 60-63, 1983.

[7] FAO, Sustainable agriculture production for international agriculture research. Report. Tech. Advisory Committee, Consulting Group on Intl. Agril. Res. (CGIAR) Pergamon, New York, 1989.

[8] Jain, S. K., Storm, B., Barthurst, J. C., Refsgaard, J. C. \& Singh, R. D., Applications of the SHE to catchments in India - Part 2: Field experiments and simulation studies on Kolar subcatchment of the Narmada River. $J$. Hydrol, 140, pp. 25-47, 1992.

[9] Klingebiel, A. A. \& Montgomery, P. H., Land capability classification, US DA Handbook, 210, Washington, pp. 21, 1961.

[10] NBSS and LUP, Proceedings National meet on soil site suitability criteria for different crops, National Bureau Soil Science and Land Use Planning, Nagpur, pp. 30, 1994. 
[11] Refsgaard, A. \& Storm, B., 'MIKE SHE', Computer models in watershed hydrology, V. P. Singh Ed., Water Resources Publication, Colorado, USA, pp. 806-846, 1995.

[12] Refsgaard, J. C., Seth, S. M., Barthurst, J. C., Erlich, M. \& Jorgensen, B., Application of SHE to catchment in India - Part II: General Results. $J$. Hydrol., 140, pp. 23-59, 1992.

[13] Singh, R., Subramanian, K. \& Refsgaard, J. C., Hydrological modelling of a small watershed using MIKE SHE for irrigation planning Agricultural Water Management, 41(3), pp.149-166, 1999.

[14] Storie, R. E., Storie index soil rating (revised). Spec. Publ. Agric. Sci. Univ. California, 3203, 1978.

[15] Sys. C., Land evaluation Part I, II and III, State University, Ghent Publications. pp. 352, 1985. 